\title{
On the influence of binder content in particleboards bonded with resins of high and low molar ratio on the formaldehyde release measured by the perforator method
}

\author{
E. Roffael • C. Behn
}

Received: 15 February 2012/Published online: 9 June 2012

(C) The Author(s) 2012. This article is published with open access at Springerlink.com

\begin{abstract}
A comprehensive literature survey and the results of investigations clearly show that the influence of resin level in particleboards on the perforator value (EN 120) depends on the molar ratio of the resin used as a binder. In case of high molar ratio resins ( $\mathrm{F}: \mathrm{U}$ 1.6:1) increasing the binder content in the boards leads to an increase in the perforator value of the boards. In contrast, boards bonded with very low molar ratio aminoplastic resins with molar ratio $\mathrm{F}: \mathrm{U}$ of $1: 1\left(\mathrm{~F}: \mathrm{NH}_{2}\right.$ 0.5:1) or even lower do not show any noticeable increase in the perforator value on raising the binder level. On the contrary, the measured perforator values may sometimes decline due to increase in the resin content in the boards. The perforator test seems to include two main processes taking place alongside each other: the physical extraction of free formaldehyde and the chemical hydrolysis process of the resin itself, induced by the moisture content of the boards. In case of low molar ratio resins, particularly at very low molar ratios (F:U 1:1 or even lower), free urea may also be present in the resin or added to the resin as a scavenger. Urea seems to react with extracted formaldehyde at high temperature during the extraction process. This lowers the perforator value without necessarily decreasing the emission at ambient conditions. Insofar, inextricably intertwined chemical processes seem to unfold during the extraction process. Additionally, the results show that
\end{abstract}

\footnotetext{
E. Roffael ( $\bowtie)$

Georg-August-Universität Göttingen, Göttingen, Germany

e-mail: eroffae1@gwdg.de

C. Behn

Büsgen-Institut, Abt. Molekulare Holzbiotechnologie und Technische Mykologie, Georg-August-Universität Göttingen, Göttingen, Germany
}

subtle differences in the perforator value in the very low formaldehyde emission region may remain without noticeable impact on the emission measured by the chamber method (EN 717-1).

Einfluss des Bindemittelgehalts in Spanplatten auf den Perforatorwert in Abhängigkeit vom Molverhältnis des verwendeten Harzes

Zusammenfassung Die Literaturauswertung und eigene Untersuchungsergebnisse lassen deutlich werden, dass das Molverhältnis des verwendeten Harzes in Holzspanplatten Einfluss auf die Beziehung zwischen Bindemittelgehalt und Perforatorwert (EN 120) nimmt. Im Bereich hohen Formaldehydgehalts im Harz bzw. hohen $\mathrm{F}: \mathrm{NH}_{2}$-Verhältnisses steigt - Literaturangaben entsprechend - der Perforatorwert mit zunehmendem Bindemittelgehalt in der Platte an, bei Verwendung von Harzen mit einem Molverhältnis F:U von 1:1 oder darunter bleibt der Perforatorwert in Abhängigkeit vom Bindemittelgehalt der Platte entweder unverändert oder nimmt sogar geringfügig $\mathrm{ab}$. Während des Prozesses der Formaldehydabgabebestimmung aus Holzspanplatten nach der Perforatormethode scheinen folgende Vorgänge stattzufinden: Zum einen die physikalische Extraktion des Formaldehyds und zum anderen eine Hydrolyse des verwendeten Harzes, induziert durch die Feuchte der hergestellten Platten. Die Hydrolyse scheint zur Bildung von Harnstoff und Harnstoffderivaten zu führen, die mit dem extrahierten Formaldehyd reagieren. Der Formaldehyd kann in der Platte auch mit Harnstoff, der als Formaldehydfänger zugegeben wird, reagieren. Das Ausmaß dieser Reaktionen scheint vom Molverhältnis des Harzes abzuhängen. Geringe ermittelte Unterschiede im Perforatorwert können deshalb ohne Bedeutung für die Emission in der Prüfkammer nach EN 717-1 bleiben. 


\section{Introduction}

Decreasing the molar ratio $\mathrm{F}: \mathrm{U}$ in $\mathrm{UF}$-resins to reach very low formaldehyde emission, as needed by the stringent standards like $\mathrm{F}^{* * * * *}$ in Japan (JIS 1460 A 2001), Carb II (2007) (ASTM E 1333) in California (USA) has a negative impact on the reactivity of the resins and leads to extended gel time and consequently to a decrease in the hardening speed of the resin during pressing. Wittmann (1982) and Sundin et al. (1987) conducted detailed studies on the influence of decreasing the formaldehyde content in UFresins on the water solubility in particleboards bonded therewith. The results reveal that lowering the molar ratio $F: U$ increases significantly the water solubility of the hardened resins in the boards. This clearly indicates that the cross-linking density of UF-resins decreases on reducing the formaldehyde content in the resins to produce emaciated products.

The results of Sundin et al. (1987) conform to work published earlier by Mayer (1978) revealing that the water solubility of resins in particleboards increases on decreasing the molar ratio $\mathrm{F}: \mathrm{U}$ in UF-resins.

\subsection{Influence of resin content on the perforator value}

In the literature, controversial results have been reported by several authors related to the influence of binder content in particle- and fibreboards on the formaldehyde release. The influence of resin content on the formaldehyde release measured by the perforator method has been studied in the past by several authors on particleboards bonded with UF-resins of high formaldehyde content (Petersen et al. 1972, 1973, 1974; Mayer 1978). According to Mayer (1978) an increase in the resin content by $50 \%$ increases the perforator value by only about $20 \%$. This result holds over a wide range of moisture content. In boards bonded with UF-resins of high molar ratio (F:U 1.6:1) a significant increase in the perforator value was found on increasing the resin content (Fig. 1).

Increasing the amount of UF-resins of a molar ratio $(\mathrm{F}: \mathrm{U}$ 1.4:1) from 5 to $12 \%$ has, in contrast, almost no influence on the formaldehyde content extracted from the sample using the perforator method (Petersen et al. 1973).

Whereas quantitative data are available addressing the influence of resin content on the perforator value in boards bonded with urea formaldehyde resins of high molar ratio, no systematic studies seem to have been reported related to the influence of molar ratio in UF-resins of molar ratio $F: U$ lower than 1:1. The behaviour of such resins may be different due to the following reasons:

Lowering the formaldehyde content in UF-resins increases the susceptibility of the hardened resins to hydrolysis in boards bonded therewith (Wittmann 1982, Sundin et al. 1987). Moreover, wood-based panels bonded with low molar ratio resins $\mathrm{F}: \mathrm{U}$ contain, in general, high amounts of still reactive free urea (Hameed et al. 2006), which can react with formaldehyde extracted from the resin leading to biased perforator values. Urea may be added to the resin as secondary urea during preparation or as a scavenger in particle- or fibreboard factory (Francis 2010).
Fig. 1 Influence of resin content on the perforator value using UF-resins with a molar ratio F:U 1.6:1 and 1.4:1 (Petersen et al. 1973) Abb. 1 Einfluss des Beleimungsgrades bzw. des Bindemittelgehalts auf den Perforatorwert bei der Verwendung von Harzen des Molverhältnisses F:U 1,6:1 und 1,4:1 (Petersen et al. 1973)

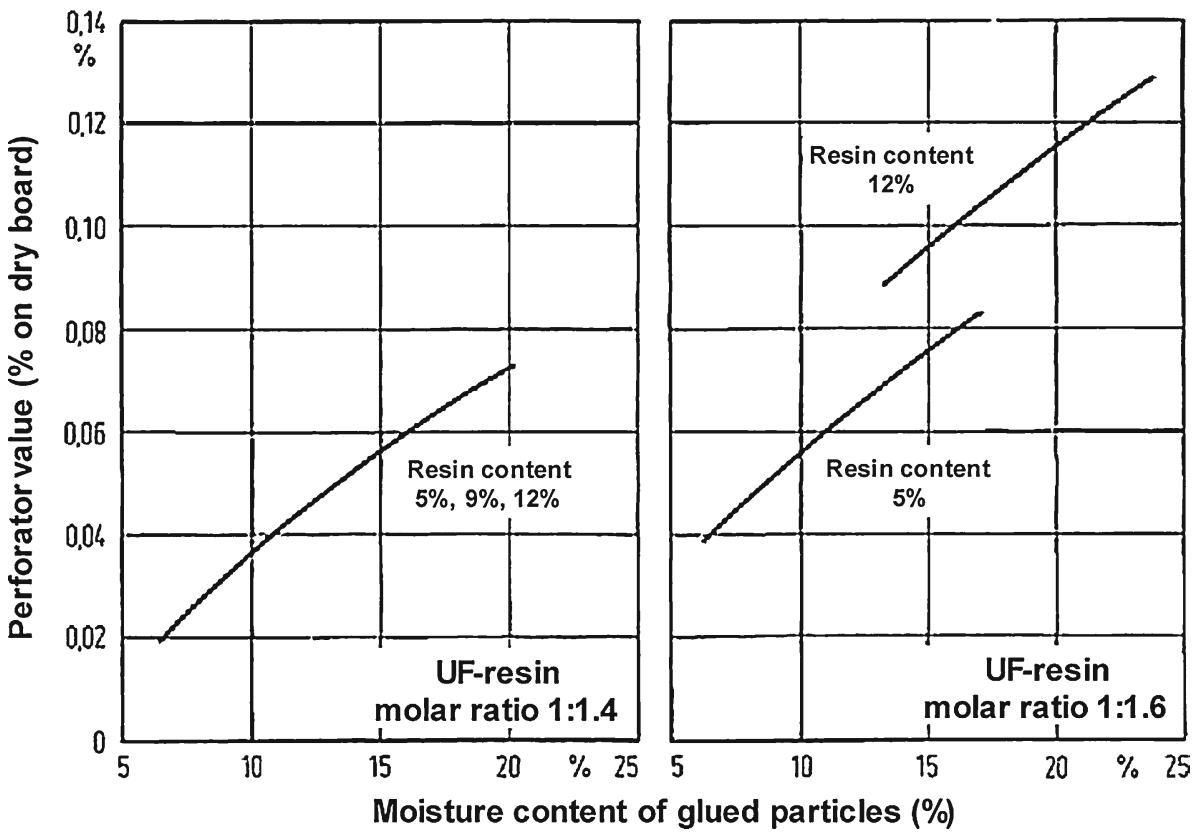




\section{Perforator method and hydrolysis of UF-resins in wood-based panels}

The measured perforator values highly depend on the moisture content of the boards. Roffael and Mehlhorn (1980) showed that between a moisture content of $\sim 3$ and $\sim 14 \%$ a more or less straight relationship exists between the measured perforator value and moisture content of the boards. Sundin (1984) pointed out the significance of the moisture content on the measured perforator value of particleboards. Moreover, Sundin (1984) found that the perforator value of UF-bonded boards can hardly be distinguished from that of wood itself after drying of the boards to nearly $0 \%$ moisture content emphasizing the relevance of the moisture content.

Jann and Deppe (1990) developed an empirical correction factor for adjusting the measured perforator value to a moisture content of $6.5 \%$; the formula based on the work of Jann and Deppe (1990) has been adopted by the standard EN 312

$\mathrm{F}=1.86-0.133 \mathrm{u}$

where $\mathrm{F}$ stands for the correction factor and $\mathrm{u}$ for the moisture content of the particleboards. According to EN 312 the correction factor is valid in the range between $\geq 3$ and $\leq 10 \%$.

During the perforator test alongside the extraction of free formaldehyde in the boards hydrolysis of the UF-resin in particle- and fibreboards induced by moisture takes place creating free formaldehyde from the resin. The amount of extractable free formaldehyde depends insofar highly on the moisture content of the board.

Due to resin hydrolysis low molecular weight degradation compounds are formed, which can act as a scavenger for the available formaldehyde formed by extraction. Free formaldehyde can also be scavenged by unreacted urea, which may be present in the board. Accordingly, with increasing amount of urea brought about by hydrolysis of the resin or added as a scavenger the amount of extractable formaldehyde decreases. Insofar, the perforator test includes an extraction and hydrolysis process induced by the moisture content of the boards as well.

The hydrolysis process seems to be highly influenced by the molar ratio of the resin. Johnsson et al. (2011) showed that the correction factor according to Jann and Deppe (1990) does not only depend on the moisture content of the boards but also on the molar ratio of the resin used in making the boards. With decreasing the molar ratio F:U more urea is formed in the hydrolysis step. By using low UF-resins increasing the binder content in the boards leads to more formaldehyde formed by hydrolysis of the resin and scavenged by the still free urea in the resin. Maybe mainly due to such reactions the perforator value becomes less responsive to the influence of the binder content in particle- and fibreboards as shown in Figs. 2 and 3. In Fig. 2, the perforator values of boards bonded with a MUFresin of molar ratio $\mathrm{F} / \mathrm{NH}_{2}$ of $0.4: 1$ are shown at three resin levels $(13.5,14.5$ and $15.5 \%)$. No scavenger was added to the resin. Alongside the perforator values, the emission of the boards according to EN 717-1 was also measured. The results reveal that the perforator values react sluggishly and increased only from 1.2 to $1.5 \mathrm{mg} / 100 \mathrm{~g}$ board on increasing the resin level from 13.5 to $15.5 \%$, whereas the emission level of the boards according to EN 717-1 remains more or less unchanged.

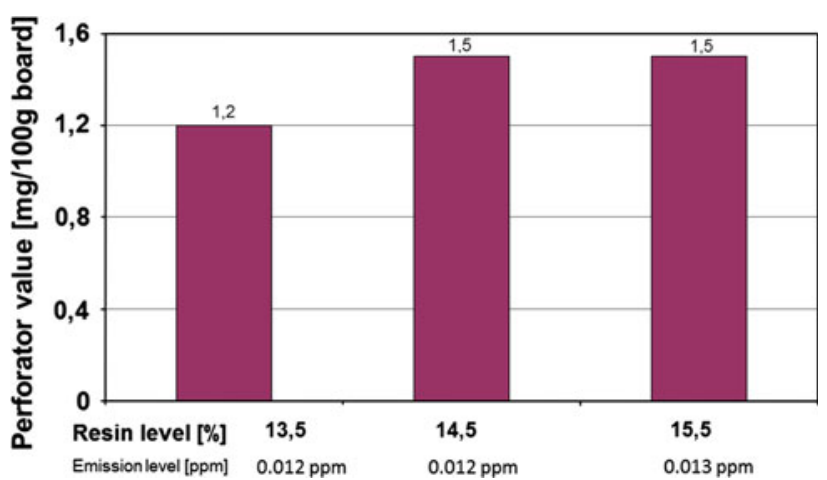

Fig. 2 Perforator values measured according to EN 120 and corresponding emission levels (EN 717-1) of boards bonded with modified UF-resins (F: $\mathrm{NH}_{2}$ 0.4:1) at different resin levels (13.5, 14.5, $\left.15.5 \%\right)$. The boards were prepared without urea based scavenger

Abb. 2 Perforatorwerte (EN 120) und entsprechende Emissionsraten (EN 717-1) von Platten, die mit modifizierten UF-Harzen ( $\left(\mathrm{F}: \mathrm{NH}_{2} 0,4: 1\right)$ und unterschiedlichem Harzanteil $(13,5 \%, 14,5 \%, 15,5 \%)$ gebunden wurden. Formaldehydfänger wurden nicht eingesetzt

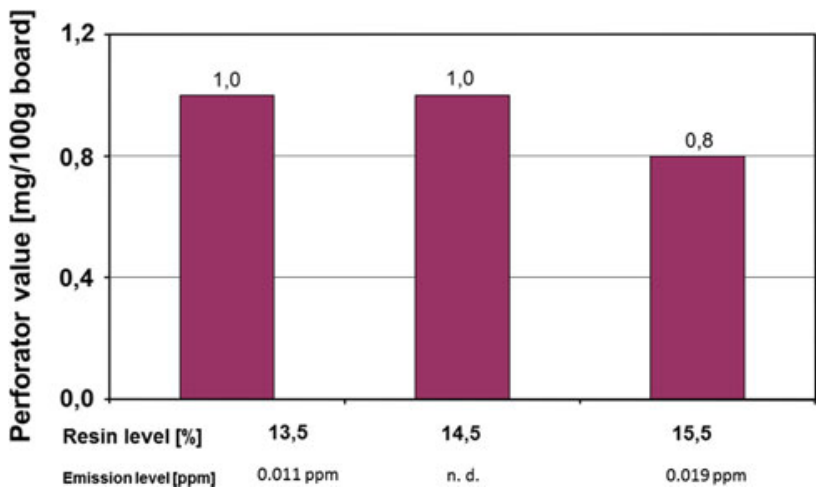

Fig. 3 Perforator values measured according to EN 120 and corresponding emission levels (EN 717-1) of boards bonded with modified UF-resins (F: $\mathrm{NH}_{2}$ 0.4:1) at different resin levels $(13.5,14.5,15.5 \%)$. The boards were prepared with urea based scavenger

Abb. 3 Perforatorwerte (EN 120) und entsprechende Emissionsraten (EN 717-1) von Platten, die mit modifizierten UF-Harzen $\left(\mathrm{F}: \mathrm{NH}_{2}\right.$ $0,4: 1)$ und unterschiedlichem Harzanteil $(13,5 \%, 14,5 \%, 15,5 \%)$ gebunden wurden. Es wurde ein auf Harnstoff basierender Formaldehydfänger eingesetzt 
In a further set of experiments a urea-based formaldehyde scavenger was added to the resin, the boards were made with the same above mentioned binder levels (13.5, 14.5 and $15.5 \%$ ). The particleboards were tested again by the perforator method (EN 120) and the emission according to EN 717-1. As can be deduced from the results (Fig. 3) a significant decrease of the perforator value takes place by adding the scavenger to the resin. However, no notable change in the emission level was found at this very low level of emission, which could hardly be distinguished from that of the wood itself. This means that subtle differences in the perforator value in the low region of emission could be insignificant to the emission measured according to EN 717-1.

\section{Conclusion}

Results of measurement of the perforator value of particleboards bonded with very low molar ratio UF-resins (F:U $<1: 1)$ revealed that the perforator value could even decrease with increasing binder level. This deviance from previously published results on the change of the perforator value with increasing binder content in boards bonded with high molar ratio resins $(\mathrm{F}: \mathrm{U}>1: 1.4)$ is explained as follows: Boards bonded with low molar ratio resins still contain unreacted urea in the resin or added as a scavenger. This free urea reacts with formaldehyde extracted from the boards leading to results biased to lower values. Accordingly, no reliable correction exists between the measured perforator values according to EN 120 and the emission in the chamber according to EN 717-1. This is a result of extremely high relevance and has to be considered in assessing the emission behavior of low fuming boards.

Open Access This article is distributed under the terms of the Creative Commons Attribution License which permits any use, distribution, and reproduction in any medium, provided the original author(s) and the source are credited.

\section{References}

CARB (2007): Proposed Airborne Toxic Control Measure (ATCM) to reduce formaldehyde emission from composite wood products. http://www.arb.ca.gov
Francis G (2010): Formaldehyde catchers: Overview and testsproduction of low formaldehyde emission wood panels EPF $S$, CARB 2. Paper presented at the 7th European wood-based panel Symposium, 13-15.10.2010, Maritim Hotel, Hannover

Hameed M, Kraft R, Roffael E (2006) Freier Harnstoff in alten Spanplatten nachweisbar. Holz-Zentralblatt 132(45):1320-1321

Jann O, Deppe H-J (1990) Zur Berücksichtigung der Materialfeuchte bei der Formaldehydmessung von Spanplatten. Holz RohWerkst 48:365-368

JIS A 1460 (2001): Building boards. Determination of formaldehyde emission-desiccator method-Japanese Industrial Standard

Johnsson B, Engström B, Roffael E (2011) Influence of molar ratio in aminoplastic resins on the dependence of the measured perforator values on the moisture content of wood-based panels. Wood Sci Technol 45:389-398

Mayer J (1978) Chemische Aspekte bei der Entwicklung formaldehydarmer Klebstoffe für die Holzwerkstoffindustrie. Paper presented at the International Particleboard Symposium, 18-20 Sept. 1978, Hamburg. See also in: Spanplatten-Heute und Morgen: 102-111, DRW-Verlag Stuttgart

Petersen H, Reuther W, Eisele W, Wittmann O (1972) Zur Formaldehydabspaltung bei der Spanplattenerzeugung mit Harnstoff-Formaldehyd-Bindemitteln; 1. Mitteilung. Holz RohWerkst 30:429-436

Petersen H, Reuther W, Eisele W, Wittmann O (1973) Zur Formaldehydabspaltung bei der Spanplattenerzeugung mit Harnstoff-Formaldehyd-Bindemitteln; 2. Mitteilung: der Einfluss der Festharzmenge, Preßzeit und Preßtemperatur. Holz RohWerkst 31:463-469

Petersen H, Reuther W, Eisele W, Wittmann O (1974) Zur Formaldehydabspaltung bei der Spanplattenerzeugung mit Harnstoff-Formaldehyd-Bindemitteln; 3. Mitteilung: der Einfluss von Härterart, Härtermenge und Formaldehyd bindenden Mitteln. Holz Roh- Werkst 32:402-410

Roffael E, Mehlhorn L (1980) Einfluß der Randbedingungen bei der Bestimmung des extrahierbaren Formaldehyds in Holzspanplatten nach der Perforatormethode. Holz Roh- Werkst 38:85-88

Sundin B (1984) The perforator value-sources of error and background values. Dynobels spans Kiredagar I Roeros, 5-7 September

Sundin B, Månsson B, Endrody E (1987) Particleboards with different contents of releasable formaldehyde. A comparison of board properties including results from four different formaldehyde tests. 21st International Symposium on particleboard/composite material. March 24-26, 1987, Washington State University, Pullman, USA

Wittmann O (1982) Investigations on the durability of aminoplastic resin bonded boards. Paper presented at the 40th meeting of the FESYP, published by FESYP Gießen, Germany 